Karolina Miłosz-Szewczyk

Uniwersytet Marii Curie-Skłodowskiej w Lublinie

(D) https://orcid.org/0000-0003-4331-8089

\title{
Kontekstualizacja absolutnych lakun językowych we fragmentach dyskursu jako źródło ich znaczenia aktualnego
}

\author{
Contertualization of Absolute Language Lacunas \\ in Fragments of Discourse as a Source of Their Current Meaning
}

\begin{abstract}
The author of this article analyses the content of using absolute linguistic lacunas in fragments of the discourse. Absolute lacunas are considered to be lexemes, which do not appear as fired expressions in Polish-German and German-Polish bilingual dictionaries and have no equivalent in the target language. The analysis of the conterts of absolute linguistic lacunas is based on the analytical categories of Critical Discourse Analysis (KAD) (JÄGER, 2004) and the intratentual layer of the multi-layered model of analysis DiMEAN (WARnKe, SPITZMÜller, 2008; 2011). As a result, the actual meaning of German absolute linguistic lacunas has been reconstructed and the lacunas have been given the status of key words and stigma words.
\end{abstract}

Key words: absolute linguistic lacuna, actual meaning, contestualization, stigma word, key word

\begin{abstract}
Abstrakt: Autorka niniejszego artykułu poddaje analizie konteksty użyć absolutnych lakun językowych we fragmentach dyskursu. Za lakuny absolutne uważa się leksemy, które nie występują jako wyrażenia hasłowe $w$ słownikach dwujęzycznych polsko-niemieckich i niemiecko-polskich ani nie mają odpowiednika w języku docelowym. Przeprowadzona analiza kontekstów występowania absolutnych lakun językowych opiera się na kategoriach analitycznych Krytycznej Analizy Dyskursu (KAD) (JÄGER, 2004) i płaszczyzny intratekstualnej modelu DIMEAN (WARnke, SPItZmüller, 2008; 2011). W jej wyniku zostało zrekonstruowane aktualne znaczenie niemieckojęzycznych absolutnych lakun językowych i został im nadany status słów kluczy i słów stygmatów.
\end{abstract}

Słowa klucze: absolutna lakuna językowa, znaczenie aktualne, kontekstualizacja, słowo stygmat, słowo klucz

\section{Wprowadzenie}

Celem autorki niniejszego opracowania jest przedstawienie procesu rekonstrukcji i wyjaśnienia aktualnego znaczenia absolutnych lakun językowych na podstawie kontekstów, $w$ których występują one we fragmentach dyskursu. Zakłada się, iż konteksty dyskursywne są źródłem znaczeń aktualnych, dzięki którym może zostać wypełniona absolutna lakuna. W toku rozważań zostanie wyjaśnione pojęcie absolutnej lakuny językowej, której istota jest przedmiotem badań $w$ ramach tworzonych teorii lakun. Uważnej refleksji wymaga również kwestia znaczenia aktualnego i konotacyjnego wynikającego z kontekstualizacji. Pokrótce 
omówione zostaną założenia Krytycznej Analizy Dyskursu (KAD)1 (JÄGER, 2004) i kryteria płaszczyzny intratekstualnej modelu DIMEAN (WARnke, SpitzmüLler, 2008; 2011) oraz dyskursywny charakter konstruowania znaczeń, na których oparta będzie analiza kontekstów występowania absolutnych lakun językowych. Zwieńczeniem rozważań teoretycznych będzie analiza fragmentów dyskursu, w których występują przykładowe absolutne lakuny językowe. Zaprezentowane zostaną ich znaczenia aktualne i podjęta będzie próba nadania im statusu słów kluczy i słów stygmatów.

\section{Pojęcie lakuny}

Słownictwem $w$ aspekcie kulturowym zajmowało się wielu polskich badaczy. Anna Wierzbicka (1997; Przekł. 2007) udokumentowała słowa klucze różnych kultur, Jerzy BARTMIŃSKı (2016) opisał koncepty kulturowe, kulturemy, wartości polskiej kultury narodowej manifestowane przez słowa klucze. Różnice i osobliwości kulturowe określa także pojęcie lakuny, stojące w centrum niniejszych rozważań.

W języku łacińskim lacuna oznacza nie tylko 'lukę', ale także 'dziurę, zagłębienie, przepaść' (por. SCHRÖDER, 1997: 10). Rosyjski językoznawca Jurij Sorokin zaczerpnął koncepcję lakuny z językoznawstwa kontrastywnego i rozwinął ją w latach sześćdziesiątych XX wieku do kategorii badań etnopsycholingwistycznych (por. PANAsıuk, 2005: 274). Od tamtego czasu lakuny stały się przedmiotem wielu badań, w tym leksykograficznych (BentivoGli, Pianta, 2000; Gouws, Prinsloo, 2008; Szerszunowicz, 2013; 2016;), nad reklamą (Grodzki, 2003), kulturowych (ERTelt-Vieth, 2006) i translatorycznych (Panasiuk, 2005; 2006; 2009).

Irina Markovina i Jurij Sorokin (2006: 22) określają lakunami wszystkie te elementy obcego tekstu kulturowego, których odbiorca nie rozumie, które wydają mu się dziwne, wymagają interpretacji i służą $w$ tekście jako sygnał obecności elementów specyficznych dla danego kraju, pochodzących z kultury, w której tekst powstał. Ich występowanie może doprowadzić do zakłócenia lub niepowodzenia komunikacji. Igor PAnAsıuK (2005: 26) twierdzi, że zestawienie z sobą systemów językowych i kontekstów prowadzi do zidentyfikowania różnic $w$ znaczeniach, a także $w$ ich kontekstualnych zastosowaniach, co $w$ etnopsycholingwistyce zostało nazwane lakuną ${ }^{2}$ W procesie porównywania kontekstów lakuna staje się oznaką międzykulturowych różnic $w$ znaczeniu, a jej powstanie jest uwarunkowane odmienną strukturą znaczenia leksykalnego w poszczególnych językach (por. PAnAsıuk, 2005: 153).

Teoria lakun (Lakunen-Theorie) rozumiana jest jako proces odkrywania, przedstawiania i wyjaśniania lakun³. Przedmiotem badań zwolenników tej teorii jest tekst jako źródło informacji kulturowej i jej międzykulturowego przekazu (por. PANASIUK, SCHRÖDER, 2006: 14). Model lakun (Lakunen-Modell), określający i charakteryzujący typy lakun, stanowi z kolei dynamiczny instrument analizy (por. ERTelt-Vieth, 2006: 53) i służy jako pomoc w inter-

1 Kritische Diskursanalyse.

2 „Die Gegenüberstellung von Sprachsystemen und Konterten führt zur Feststellung von Differenzen in Bedeutungen, sowie in ihren kontextuellen Anwendungen, die in der Ethnopsycholinguistik die Bezeichnung Lakunen erhalten hat" (PANAsıuk, 2005: 26).

3 „Aufdecken, Nachzeichnen, Erklären” (Eertelt-Vieth, 2006: 66). 
pretacji obcojęzycznych znaczeń (por. Panasıuk, 2006: 98). Astrid Ertelt-Vieth (2005: 316) podkreśla jednocześnie, że etnopsycholingwistyczna teoria lakun i model lakun mają swoje korzenie $w$ studiach tłumaczeniowych. Co więcej, poznawczy aspekt znaczenia leksykalnego dotyka kulturowych aspektów semantyki i jest jednocześnie uważany za przedmiot badań psycholingwistycznych (por. ERTELT-VIETH, 2005: 14).

Markovina i Sorokin (2006: 26) dzielą lakuny na językowe i kulturowe. Warto w tym miejscu zaznaczyć, że w niniejszym opracowaniu uwaga skupia się na lakunach językowych, które ujawniają się $w$ zestawieniu z sobą dwóch systemów językowych. Na podstawie takiego zestawienia można stwierdzić, czy są one relatywne czy absolutne. Relatywne lakuny językowe dotyczą różnic $w$ częstotliwości ich stosowania oraz rozpowszechnienia i nie stanowią tu przedmiotu rozważań. Absolutne lakuny językowe stanowią rezultat braku odpowiednika $w$ jednym z porównywanych języków (por. PANASIUK, SCHRÖDER, 2006a: 16). Absolutna lakuna została zdefiniowana przez PANAsıuka (por. 2001: 295) jako element znaczenia w obcej kulturze, który nie ma żadnych (częściowych lub względnych) odpowiedników w systemie semantycznym innej kultury. Jej znaczenie może zostać przekazane $w$ formie opisowej - za pomocą związków wyrazowych (por. MARKovina, Sorokin, 2006: 23). Lakuny wymagają komentarza, parafrazy, uzupełnienia i kompensacji (por. PANASIUK, SCHRÖDER, 2006b: 312).

Na potrzeby przeprowadzonej analizy jako absolutne lakuny językowe zostały sklasyfikowane niemieckojęzyczne leksemy, które nie występują jako wyrażenia hasłowe w następujących słownikach dwujęzycznych polsko-niemieckich i niemiecko-polskich: PONS - Słownik online, LANGENSCHEIDT - Słownik Internetowy, DEPL - Słownik online niemiecko-polski i polsko-niemiecki, DIKI - Multimedialny słownik niemieckiego online.

\section{Znaczenie $w$ kontekście}

Kluczową kwestię dla niniejszego opracowania stanowi kontekst, w którym występują absolutne lakuny językowe. Tylko na jego podstawie możliwa jest rekonstrukcja ich znaczeń, gdyż - jak wspomniano - nie są one notowane w słownikach dwujęzycznych. Na podstawie tezy Dietricha Bussego (1987: 86) można założyć, iż pojedyncze słowa (w tym wypadku lakuny) mają znaczenie tylko wtedy, kiedy są używane w konkretnym kontekście i tylko w świetle systemów znaczeniowych, jakie tworzy język. Nie są one zatem rozpatrywane $w$ odosobnieniu, lecz $w$ kontekście większych językowych i pozajęzykowych powiązań (por. SpIEss, 2010: 210). Busse (2007: 82) rozumie kontekst jako wszechstronne tło epistemiczno-poznawcze, które umożliwia przede wszystkim zrozumienie poszczególnych znaków językowych (łańcuchów) lub aktów komunikacji ${ }^{4}$ Istotną funkcję pełnią środki językowe, za których pomocą wypowiedź jest umiejscowiona w konkretnej sytuacji (por. GLÜck, 1993: 345). Kontekst sytuacyjny jest zatem niezbędny do zrozumienia słów (por. BuSSE, 1987: 167). To kontekst wskazuje na interpretację wyrażenia językowego (AuER,

\footnotetext{
4 „Den umfassenden epistemisch-kognitiven Hintergrund, der das Verstehen einzelner sprachlicher Zeichen(ketten) oder Kommunikationsakte überhaupt erst möglich macht” (BuSSE, 2007: 82).
} 
1999: 167)5. Busse (2007: 102) podkreśla, że kontekstów należy poszukiwać, a gdy zostaną odnalezione, należy je odtworzyć i przedstawić, gdyż dostarczają elementów wiedzy niezbędnych do prawidłowego zrozumienia zdania, tekstu. Ponadto $w$ znaczeniu słów odzwierciedla się społeczeństwo z jego rozwojem historycznym (SEIDEL-Slottr, 1960: 40). Ingo Warnke i Jürgen Spitzmüller (2008: 7) są zdania, że znaczenie jest zawsze specyficzne, nadawane tylko $w$ dyskursie i wynika z kontekstualizacji, a ta z kolei polega na wykorzystaniu przez mówców i słuchaczy znaków werbalnych i niewerbalnych w celu powiązania tego, co zostało powiedziane $w$ określonym czasie i miejscu, z wiedzą zdobytą w wyniku wcześniejszych doświadczeń (por. Gumperz, 1982: 230, za: Glück, 1993: 346). Peter Auer (1999: 174) definiuje kontekstualizację jako wzajemną relację trzech elementów umożliwiających interpretację. Należą do nich: środki wyrazu, znaczenia i zasoby wiedzy. John Gumperz (1982, za: Auer, 1999: 167) jest zaś zdania, że kluczową kwestię w podejściu do kontekstualizacji stanowi fakt, że język nie jest tylko determinowany przez kontekst jego użycia, ale również tworzy konteksty, co odróżnia kontekstualizację od kontekstu, który ma charakter statyczny. Kontekstualizacja to zatem proces umiejscowiania znaków językowych w przestrzeni wiedzy niezależnie od tego, czy wiedza ta jest prawidłowa, spójna, sprawdzona, czy nie (por. Busse, 2007: 102). Podstawowa językowa płaszczyzna kontekstualizacji obejmuje jednostki wyrazowe lub pojedyncze znaki. Busse (2007: 87-90) wyróżnia cztery formy kontekstualizacji:

1) kontekstualizacja słów w zdaniu (ewentualnie w tekście) jako działanie interpretacyjne, na które decydujący wpływ mają hipotezy o znaczeniu zdaniowo-semantycznym (Busse, 2007: 88);

2) kontekstualizacja słów w polu leksykalno-semantycznym zawierającym stałe relacje semantyczne (takie jak synonimia, antonimia czy komplementarność) stanowiąca unikatową formę kontekstualizacji, ponieważ nie można jej konsekwentnie przypisać do jednej z innych form kontekstualizacji znaków słownych (składniowych bądź związanych z tekstem) (Busse, 2007: 88);

3) kontekstualizacja słów $w$ ramach predykacyjnych (Prädikationsrahmen) będąca kluczową dla semantyki zdania (Satzsemantik), gdzie jedno słowo może aktywować najbardziej zróżnicowane ramy wiedzy (Wissensrahmen) związane z tekstem i ze światem (BussE, 2007: 89);

4) kontekstualizacja słów $w$ ramach wiedzy o tekście i świecie - gdy z wiedzą na temat danego pojęcia/słowa łączy się wiedza na temat ram predykacyjnych, $w$ jakich to słowo może wystąpić; ramy te mogą być analizowane jako ramy wiedzy, a tym samym jako struktury wiedzy dotyczącej codzienności, jako rzeczywiste doświadczenia; każdy znak językowy jest zatem związany ze znajomością ram wiedzy, w których on sam lub jego treść semantyczna mogą być osadzone (BUSSE, 2007: 89-90) ${ }^{6}$; z punktu widzenia semantyki zdania i analizy dyskursu ramy wiedzy są najważniejszymi formami kontekstualizacji związanej ze słowem (Busse, 2007: 90).

5 „Der Kontext bestimmt die Interpretation des sprachlichen Ausdrucks” (AuER, 1999: 167).

${ }^{6}$ "Mit jedem Sprachzeichen ist ein Wissen darüber verbunden, in welchen Wissensrahmen in welcher Position dieses Sprachzeichen (bzw. sein semantischer Gehalt) eingebettet sein kann" (BussE, 2007: 89-90). 


\section{Znaczenie leksykalne, aktualne, konotacyjne}

Katja Kessel i Sandra Reimann (2017: 186) twierdzą, że słowa mogą mieć znaczenie pierwotne i wtórne, zazwyczaj występując w kontekstach, w których mają konkretne, aktualne znaczenie. W leksykologii operuje się pojęciem znaczenia leksykalnego, które odnosi się do wszystkich jednostek leksykalnych (por. MARкоwsкı, 2012: 43). Hadumod BussmanN (1990: 449) określa je jako sumę wszystkich (dosłownych i przenośnych) znaczeń leksemu na poziomie langue, które są realizowane na poziomie parole $w$ kontekście jako specyficzne, aktualne znaczenia. Aktualne znaczenie mają zatem słowa w użyciu, określone i zdeterminowane przez kontekst, co oznacza, że zostaje im przypisane znaczenie w wypowiedzi, tzn. w konkretnej sytuacji komunikacyjnej (por. KNIPf-Komlósı, RADA, BERnÁth, 2006: 142). Andrzej Marкowskı (2012: 43) zestawia znaczenie leksykalne i aktualne, zaznaczając, że są wobec siebie przeciwstawne. „To znaczenie [aktualne], zwane też kontekstowym, tekstowym lub pragmatycznym, występuje $w$ danej sytuacji komunikacyjnej, jest więc przypisane konkretnej realizacji tekstowej określonego leksemu” (MARKowskı, 2012: 43). „Znaczenie leksykalne zwane jest też znaczeniem słownikowym, systemowym albo potencjalnym. [...] Jest ono zapisywane $w$ formie definicji danego wyrazu" (MАRкоWSKı, 2012: 43). W tym miejscu należy zaznaczyć, że celem podjętym w niniejszym opracowaniu nie jest stworzenie definicji leksykalnej (słownikowej) ${ }^{7}$ wybranych absolutnych lakun językowych, lecz wyjaśnienie ich znaczenia poprzez opisanie kontekstów, w których występują we fragmentach dyskursu.

Znaczenie konotacyjne jest uważane za dodatkowe, pomocnicze, obejmujące częściowo czysto subiektywne, indywidualne skojarzenia, a częściowo obiektywne, lingwistyczne zjawiska użytkowe (por. KNIPf-Komlósı, RAdA, BernÁth, 2006: 138). Znaczenie konotacyjne informuje o warunkach stosowania leksemu, o intencji i przedmiocie komunikacji oraz konkretnej sytuacji komunikacyjnej (por. SchIPPAn, 1984: 156). Konotacje mogą odnosić się według Elisabeth Knıpf-Komlósı, Roberta Rada i Csilli Bernáth (2006: 139) do następujących obszarów: a) płaszczyzny komunikacyjnej, czyli sytuacji komunikacyjnej, w której użycie danego słowa jest stosowne (np. w języku potocznym); b) komunikacyjnych obszarów funkcjonowania (np. język techniczny); c) regionalnej formy użycia słowa; d) czasu; e) zakresu politycznego; f) stanu emocjonalnego. Erhard AgRICola (por. 1982: 15) wyróżnia dwa rodzaje konotacji: a) konotacje charakterystyczne dla leksykonu, które opierają się na znaczeniu aktualnym i podsystemach językowych oraz b) konotacje charakterystyczne dla komunikacji, które zależą od postaw i emocji mówcy. Co stwierdza Urszula TopсzEWSKA (2005: 245), konotacje zawierają stosunkowo stałe skojarzenia z danym zwrotem, ale nie są częścią jego definicji, dlatego też należy uznać je za subiektywny składnik znaczenia.

7 Ponadto przedstawione rozważania nie dotyczą statusu ontologicznego lakuny, celem nie jest również przypisanie jej statusu neologizmu, dla którego decydujący jest czynnik czasowy. W kontekście analizy relacji lakuny i neologizmu należy natomiast zaznaczyć, że lakuna może zostać zniwelowana w języku docelowym za pomocą neologizmów (por. PAnAsıuk, 2005: 158). 


\section{Dyskurs i dyskursywny charakter konstruowania znaczeń}

Studia nad dyskursem były i są obecnie podejmowane w wielu pracach badawczych nauk społecznych i humanistycznych, co otworzyło drogę ku wielu możliwościom jego interpretacji i sprawiło, że analiza dyskursu stała się interdyscyplinarnym narzędziem, a sama definicja terminu dyskurs uległa rozmyciu i jest formułowana przez badaczy zgodnie z ich celami badawczymi i nawiązaniami do istniejących szkół dyskursu. Nie wykształciła się również jedna spójna metodologia analizy dyskursu. „Dyskurs, analiza dyskursu i lingwistyka dyskursu weszły jednak na stałe do arsenału teoretycznego, metodologicznego oraz programowego lingwistyki" (CzAchur, 2020: 8). Dyskurs (jako przedmiot badań lingwistycznych) opisuje „relację między treściami językowymi (leksykalnymi) a pozajęzykowymi (kontekstowymi)" (Synowiec, 2013: 392). Nawiązując do koncepcji Ferdinanda de Saussure'a, Maciej CzERwı́́sKı stwierdza, że „przedmiotem badań [dyskursu] nie jest język jako system (langue), lecz jako jego konkretne aktualizacje (parole), ujmowane w wielowymiarowej rzeczywistości kulturowej, historycznej i społeczno-politycznej (dyskurs). Dyskurs to zatem komunikat powstały w jakimś kontekście" (2016: 43).

Busse (2000: 46) określa dyskurs jako płaszczyznę kontekstualizacji ${ }^{8}$, a dyskursy stanowią o powiązaniach kontekstowych ${ }^{9}$ (Busse, 2007: 81), które autor dzieli na:

1) zamierzone, jawne kontekstualizacje, które można stwierdzić na podstawie kryteriów, takich jak: tematyzacja w nagłówkach, specyfikacje tematu, pojęcia przewodnie, jednoznaczne sformułowania, zamierzone konotacje;

2) niezamierzone, ale świadome kontekstualizacje, do których oznak należą: pojedyncza, wyraźna tematyzacja, dyskursywne lub językowe manifestacje wyartykułowanych kontekstualizacji;

3) niezamierzone, nieświadome kontekstualizacje, które można stwierdzić jedynie za pomocą analizy; Busse określa je jako problematyczne, gdyż z jednej strony $w$ dużym stopniu bazują na teorii i opisie, z drugiej zaś - należą do najciekawszych form relacji dyskursywnych, powiązania kontekstowe muszą być oparte na wiarygodnym analitycznym opisie, zilustrowane przykładami, a interpretacja tekstu i opis znaczenia powinny być intersubiektywnie i naukowo weryfikowalne (por. Busse, 2000: 44-45); stosowanie uznanych metod głęboko semantycznej analizy w celu pokazania relacji dyskursywnych i sformułowanie dobrze uzasadnionej i weryfikowalnej hipotezy powinny wystarczyć za dowód istnienia relacji dyskursywnej jako obiektu ukonstytuowanego przez naukową analizę i perspektywę (Busse, 2000: 44-45).

Zgodnie z podziałem powiązań kontekstowych Bussego absolutne lakuny językowe można zatem zakwalifikować do grupy trzeciej, czyli niezamierzonych, nieświadomych kontekstualizacji, które należy wydobyć za pomocą analizy semantycznej i opisu znaczenia.

Dyskursy jawią się jako działania komunikacyjne, których realizacja sytuuje się $w$ konkretnym kontekście poznawczym, a ten wymaga wyjaśnienia (por. Busse, 1987: 173). Według badacza dyskurs jest zmienną, która przyczynia się do tworzenia porządków i struktur w modelach świata (np. w wiedzy encyklopedycznej) (Busse, 2000: 47). WARnKe

\footnotetext{
8 „Diskurs als Ebene der Kontextualisierung” (BuSSE, 2000: 46).

9 „Diskurse markieren [...] Kontextualisierungszusammenhänge” (BusSE, 2007: 81).
} 
i SPItzmüller (2008: 14-15) określają dyskurs jako formację użycia języka (Gebrauchsformation), a zatem każda semantyczna analiza dyskursu jest zakotwiczona w warstwie językowej w celu wyłonienia się znaczeń (por. WARnke, 2007: 17). Właśnie w dyskursie ma miejsce proces generowania znaczenia polegający na relacji między językowymi i pozajęzykowymi komponentami opisywanego fragmentu rzeczywistości. W ramach analizy dyskursu dokonuje się rejestrowanie, a także rekonstrukcja tych zależności pozwalająca "dostrzec w dyskursie utrwaloną praktykę społeczną" (SYnowiec, 2013: 392). W takim świetle zrozumiałe wydaje się stwierdzenie Waldemara CzAchurA, że „dyskursy współtworząc rzeczywistość, współtworzą znaczenie i sens procesów, zjawisk, przedmiotów itd." (2020: 166).

Constanze SpIEß (2010: 207) podkreśla, że „nie istnieją żadne przeddyskursywne i stałe znaczenia", są one kształtowane w dyskursie i dookreślone poprzez kontekst. Co za tym idzie „funkcję językowych fenomenów można zrozumieć dzięki ich umiejscowieniu w dyskursie; fenomeny językowe dają się opisać zawsze $w$ połączeniu i zakorzenieniu $w$ większych związkach" (SPIEß, 2010: 207). Aby zrekonstruować znaczenie słowa w dyskursie, należy, analizując pojedyncze słowa zastosowane w dyskursach, wziąć pod uwagę kolejne poziomy strukturalno-językowe, a także uwzględnić czynniki strukturalne, funkcjonalne, tematyczne, sytuacyjno-kontekstowe mające istotny wpływ na ich znaczenie (SPIEB, 2010: 215).

Ważną rolę $w$ niniejszym opracowaniu odgrywają założenia KAD (JÄGER, 2004) oraz modelu DiMEAN Warnkego i Spitzmüllera $(2008$; 2011), ponieważ są one punktem wyjścia do analizy dyskursywnej kontekstów występowania absolutnych lakun językowych. Zaprezentowane $w$ dalszej części tekstu metody zostaną użyte do analizy i interpretacji tekstów, które $w$ przedstawionej analizie traktowane są jako fragmenty dyskursywne.

Krytyczna Analiza Dyskursu według koncepcji Siegfrieda JäGERA (2004) ma za zadanie badać relacje języka i społeczeństwa pod kątem aspektu władzy. Zasadnicze są dla niej kwestie wykluczenia, niesprawiedliwości i dyskryminacji, ale i wiedzy, a więc świadomości zbiorowej. „Krytykowanie dyskursów ma również na celu pokazywanie możliwości alternatywnych użyć języka, nominalizacji, a także dyskursywnie uwarunkowanych opozycji" (CzAchur, 2020: 179). JÄGER (2004: 132) definiuje dyskurs jako przepływ wiedzy, względnie zasobów wiedzy zbiorowej, na przestrzeni czasu' ${ }^{10}$. Teksty zaś traktuje jako zjawisko ponadindywidualne, a więc wytworzone przez społeczeństwo, a wyrażające treści mające istotne znaczenie dla konkretnej społeczności i wywierające wpływ na procesy społeczne (JÄGER, 2004: 15). Przedmiotem badań KAD są fragmenty dyskursu (Diskursfragmente), które badacz definiuje jako wyselekcjonowane teksty bądź części tekstów. Skończony zbiór tematycznie jednorodnych fragmentów dyskursywnych tworzy wątki dyskursywne (Diskursstränge), które mogą się na siebie nakładać, krzyżować się z sobą (Diskursstranguerschränkung). To one określają płaszczyzny dyskursywne, takie jak: dyskurs naukowy, dyskurs polityczny, dyskurs medialny, dyskurs praktyk codziennych (por. KumifGA, NowickA, 2011: 142) itd., które w całości składają się na ogólny dyskurs społeczeństwa (gesamtgesellschaftlicher Diskurs) (KUMIEGA, NowICKA, 2011: 117). JÄGER (2004: 175) opracował procedurę badawczą składającą się z dwóch etapów: analityczno-materiałowego (punkty 1-4) i analityczno-interpretacyjnego (punkt 5). Obejmuje ona:

10 „Als Fluß von Wissen bzw. sozialen Wissensuorraten durch die Zeit” (JÄGER, 2004: 132). 
1) analizę ram instytucjonalnych (kontekst instytucjonalny: medium, miejsce $w$ gazecie, autor, wydarzenia itp.);

2) analizę powierzchni tekstu (układ graficzny, jednostki sensu, nośniki znaczenia, poruszane tematy);

3) analizę środków retoryczno-lingwistycznych (analiza na poziomie mikro np. idiomów, przysłów, słownictwa, stylu, aktorów, odniesień referencyjnych);

4) analizę wypowiedzi pod kątem treści i ideologii (obraz człowieka, pojmowanie techniki, wyobrażenie przyszłości itp.),

5) interpretację wybranego fragmentu dyskursu.

Model wielopoziomowej lingwistycznej analizy dyskursu (Diskurslinguistische MehrEbenen-Analyse = DIMEAN) opracowany przez WARnkEgo i SPITzMüLlera (2008) traktowany jest przez samych badaczy jako wzór metody, którą może stosować na gruncie lingwistyki dyskursu opartej na danych językowych. Model daje możliwość łączenia płaszczyzn: tekstowej, działania i kontekstu. Autorzy uwzględnili trzy poziomy: płaszczyznę intratekstualną, aktorów i transtekstualną, do których analizy służą konkretne, przypisane do płaszczyzn, metody lingwistyczne i kategorie analityczne. Autorzy postulują badanie inwentarza leksykalnego $w$ ramach analizy dyskursu (por. WARnKe, SPITZMÜLler, 2008 : 26). W ramach płaszczyzny intratekstualnej dokonywana jest analiza jednostek leksykalnych, propozycji i struktury tekstu (WArnke, Spitzmüller, 2008: 25). Tę płaszczyznę CzACHUR (2020: 198) określa „płaszczyzną warsztatową”. Istotną dla niniejszego opracowania płaszczyzną jest analiza słowa. Dokonujący jej skupia się na jednostkach jedno- i kilkusłownych. Zgodnie z modelem DIMEAN mogą one mieć status słów kluczy (Schlüsselwörter), słów stygmatów (Stigmawörter), nazw (Namen) i wyrażeń ad-hoc (Ad-hoc-Bildungen) (por. Warnke, Spitzmüller, 2008: 26). Słowa klucze to jednostki słowne, które reprezentują ideały konkretnej grupy/epoki, a ich znaczenia kontekstowe i konotacyjne warunkują dyskurs. Słowa stygmaty używane są w celu stygmatyzacji, a więc naznaczenia osób, przedmiotów, zjawisk poprzez pejoratywny ich opis. Nazwy to w szczególności toponimy, które zaznaczają granice danej przestrzeni dyskursu, lokalizując go pojęciowo i przestrzennie. Wyrażenia ad-hoc są definiowane przez badaczy jako formy językowe o chwilowym charakterze, ściśle powiązanym z kontekstem. Istotną kwestią jest, że może dojść do krzyżowania się kategorii $w$ ramach analizy słowa (WArnKe, SPItzmüLler, 2008: 26).

\section{Analiza dyskursu w kontekście}

W tym punkcie zostaną przeanalizowane dwa przykłady niemieckojęzycznych absolutnych lakun językowych $w$ kontekstach, w których występują, i w określonych fragmentach dyskursu zaczerpniętych z mediów elektronicznych. Wybrane przykłady leksemów wywodzą się z języka potocznego i należą do płaszczyzny dyskursu praktyk codziennych Alltagsdiskurs (wg JÄGER, 2004). W procesie kontekstualizacji zostanie zrekonstruowane aktualne znaczenie lakun. W analizie przedstawionych $w$ dalszej części tekstu fragmentów dyskursu, w których występują absolutne lakuny językowe, pomocne będą zarówno procedura badawcza JÄGERA (2004), jak i kryteria płaszczyzny intratekstualnej modelu DIMEAN 
WARnKego i Spitzmüllera $(2008 ; 2011)$, zgodnie z którymi zaprezentowane lakuny zostały sklasyfikowane jako słowa stygmaty i słowa klucze.

\section{der Sitzpinkler (I.mn. die Sitzpinkler)}

Według niemieckiego słownika jednojęzycznego DUDEN Sitzpinkler to ktoś, kto siada na toalecie $w$ celu oddania moczu'11. Słownik wskazuje, iż leksem wywodzi się z języka potocznego (Umgangssprache), ale nie podaje żadnych przykładów jego użycia. Poniżej zostaną zaprezentowane konteksty, w których występuje absolutna lakuna językowa Sitzpinkler. Jak już wspomniano, cytowane wcześniej teksty bądź części tekstów będą traktowane jako fragmenty dyskursów (JÄGER, 2004).

1. Dziennik „Der Tagesspiegel” zamieścił w dniu 13 lipca 2003 roku następujące zdanie: „Damals wollte man uns zu Sitzpinklern ummodellieren, sogar auf der Herrentoilette”12. Tematem fragmentu dyskursu jest sposób załatwiania naturalnej potrzeby, który według aktora dyskursu (mężczyzny, autora wypowiedzi) odbiega od normy rozpowszechnionej wśród mężczyzn. Zaimek osobowy (uns) wskazuje na przynależność aktora do grona mężczyzn, a więc do konkretnej wspólnoty. Nadawca ironizuje wypowiedź poprzez dobór słów („zu Sitzpinkler ummodelieren, sogar auf den Herrentoilette”), podkreślając, że próbowano zmienić męski sposób załatwiania naturalnej potrzeby (w domyśle na damski), który miałby obowiązywać nawet $w$ męskiej toalecie. Absolutna lakuna językowa jest $w$ tym fragmencie słowem kluczem, do którego odnosi się cały sens wypowiedzi.

2. W tekście zamieszczonym w gazecie "Süddeutsche Zeitung” z 22 września 2003 roku ukazało się następujące zdanie: „Mittlerweile ist auch noch der Frauenversteher und der Sitzpinkler dazugekommen, außerdem der Abnicker, der Fleischverweigerer und der Chefgrüßer"13, które jest źródłem innych określeń mężczyzn nieodpowiadających ich stereotypowemu wizerunkowi. Należą do nich: rozumiejący kobiety (Frauenversteher), potakiwacz (Abnicker), niejedzący mięsa (Fleischverweigerer), pozdrawiający szefa (Chefgrüßer). Określenia te wzbudzają negatywne konotacje wobec osób, których dotyczą, a dotyczą ludzi, którzy chcą się wkupić w łaski, przypodobać komuś albo wyróżniają się, ponieważ mają inne nawyki - na przykład żywieniowe. Sitzpinkler jest jednym z wielu słów kluczy, które opisują takiego mężczyznę. Z całą pewnością jest jednocześnie słowem stygmatem, gdyż wzbudza negatywne konotacje, pejoratywnie opisując mężczyzn jako "podlizywaczy”, „wazeliniarzy".

3. W jednym z tekstów w gazecie „Bild” z 9 kwietnia 2001 roku pojawiło się zdanie: „Im Büro, im Fitness-Studio, an der Theke - Frauen lachten sich schlapp über Begriffe wie »Warmduscher«, »Winselhengst«, »Sitzpinkler« oder »Turnbeutelvergesser «"14. Omawiane słowo należy do grupy określeń, z których śmieją się kobiety w biurze, na siłowni, przy ladzie, takich jak: 'biorący ciepły prysznic' (Warmduscher, w słowniku PONS przetłuma-

11 DUDEN: „[...] jemandem, der sich zum Urinieren auf die Toilette setzt”.

12 Cytat został zaczerpnięty z korpusu DWDS [online: https://www.dwds.de/wb/Sitzpinkler; data dostępu: 15.07.2020], nie był możliwy dostęp do całego tekstu, dlatego analiza niniejszego fragmentu została przeprowadzona $w$ skali mikro (zdanie).

13 Por.: [online: https://www.dwds.de/wb/Sitzpinkler; data dostępu: 15.07.2020].

${ }^{14}$ Por.: [online: https://www.dwds.de/wb/Sitzpinkler; data dostępu: 15.07.2020]. 
czone jako „mięczak”), 'skomlący ogier' (Winselhengst ${ }^{15}$, w wolnym, dosłownym tłumaczeniu; oksymoron), 'zapominający worka na trening' (Turnbeutelvergesser). Określenia te są pejoratywne, na co wskazuje kontekst ich użycia, a ich repertuar opisuje mężczyznę, który nie odpowiada stereotypowi. Lakunę Sitzpinkler można sklasyfikować jako słowo stygmat również $w$ tym kontekście jego użycia, gdyż określa mężczyzn publicznie wyśmiewanych przez płeć przeciwną.

4. Na stronie internetowej ${ }^{16}$ anglojęzycznego „The Guardian” 21 sierpnia 2010 roku ukazał się artykuł Unthinkable? Having a sit down, którego tytuł już wyraźnie określa siadanie mężczyzn na desce toaletowej jako coś nie do pomyślenia. Oto jego fragment:

Should British men learn from their German counterparts, and take to sitting down to pee? You may not want to know this - and it would be sensible to wait until after breakfast before reading any further - but, apparently, lots of German men nowadays routinely sit down to pee. From quite early on, so it is claimed, German sons are taught that being a Sitzpinkler - translate it yourself - is the done thing and that being a Stehpinkler is simply antisocial. The purpose of this social revolution hardly needs detailed explanation. Stand-up men, let it simply be said, are messier than their seated brethren - and almost never bother to clean up. In some German homes, little notices are tacked to the underside of the toilet seat so that seat-raising males are reminded to consider their options. In others, a ghostly little gadget called a Spuk - a spook - similarly attached to the underside issues a verbal warning to prospective standers. When these gadgets first came on the market they were available in a variety of voices, including those of former chancellors Helmut Kohl and Gerhard Schröder. Nearly two million flew off the shelves, producing one of those unerpected but decisive changes in human behaviour which have helped to make modern German men what they are. All of which raises the question of whether British men might learn from the Germans. British women would certainly approve. And a little gadget with a David Cameron voice reminding British men not to raise the seat might prove to be one of the coalition government's more lasting and transformational achievements.

Już na wstępie do artykułu pada ostrzeżenie skierowane do czytelników, by nie zasiadali do jego lektury przed śniadaniem, gdyż treść może wywołać u adresatów obrzydzenie („it would be sensible to wait until after breakfast before reading any further"). Aktorami przywołanego fragmentu dyskursu są niemieccy i brytyjscy mężczyźni, stojący wobec siebie $w$ opozycji. Wielu Niemców rutynowo siada, oddając mocz, w przeciwieństwie do ich kolegów z Wielkiej Brytanii. Synowie Niemców są uczeni od wczesnych lat na tzw. sitzpinklerów, gdyż bycie stehpinklerem (a więc mężczyzną, który oddaje mocz na

${ }^{15}$ Określenie Winselhengst wywodzi się od określenia Winselstute (dosł. 'skomląca klacz'), użytego w skeczu popularnego niemieckiego komika Loriota jako określenie obraźliwe, oznaczające głupią, próżną kobietę (por.: [online: https://www.mundmische.de/bedeutung/4596-Winselstute; data dostępu: 17.07.2020]).

16 Por.: [online: https://www.theguardian.com/commentisfree/2010/aug/21/unthinkable-having-a-sit-down; data dostępu: 18.07.2020]. 
stojąco) jest aspołeczne („being a Stehpinkler is simply antisocial”), co może wiązać się $z$ wykluczeniem i stygmatyzacją. Proces uczenia dzieci jest określony $w$ artykule jako rewolucja społeczna („social revolution”), której przyczyną jest higiena, a raczej jej brak w przypadku stehpinklerów, którzy nigdy nie sprzątają po sobie („,and almost never bother to clean up"). Autor artykułu opisuje niemieckie domy, w których umieszcza się od spodu deski sedesowej notatkę będącą przypomnieniem, by usiąść, wskazówką dla mężczyzn podnoszących sedes. W innych domach tę samą funkcję pełni gadżet zwany Spuk (tłum. straszydło) - wydający dźwiękowe ostrzeżenie, a dostępny na rynku w wersji z przeróżnymi głosami, również byłych kanclerzy Helmuta Kohla i Gerharda Schrödera. Według autora wszystkie te elementy miały wpływ na zmianę zachowania niemieckich mężczyzn. Artykuł zakończony jest ironicznym pytaniem skierowanym do Brytyjczyków, czy mogliby uczyć się od Niemców: „All of which raises the question of whether British men might learn from the Germans?", czemu brytyjskie kobiety z pewnością by przyklasnęły („British women would certainly approve”). Pojawia się również ironiczne stwierdzenie, że gadżet z głosem Davida Camerona może okazać się jednym z trwalszych i bardziej transformacyjnych osiągnięć koalicyjnego rządu („a little gadget with a David Cameron voice reminding British men not to raise the seat might prove to be one of the coalition government's more lasting and transformational achievements"). W analizowanym fragmencie dyskursu lakuna Sitzpinkler jest słowem kluczem, do którego wielokrotnie nawiązuje autor tekstu, a jednocześnie antonimem pojęcia Stehpinkler. Ponadto Sitzpinkler jest słowem stygmatem, gdyż $w$ artykule populacja niemieckich mężczyzn została potraktowana jako pozostająca $w$ opozycji do brytyjskich mężczyzn określanych słowem Stehpinkler.

5. Na blogu strony www.buurtaal.de ${ }^{17} 22$ września 2011 roku zamieszczono wpis: „Starke Männer braucht das Land. Die Gegenbewegung konnte natürlich nicht ausbleiben. So sehen sich jetzt die Sitzpinkler, Zebrastreifenbenutzer, Landungsklatscher, Anschnaller, Sofortspüler und Handbuchleser mit heldenmütigen Kampfhundstreichlern, Hooligananremplern, Geisterfahrerüberholern, Polizisten und Eiswürfelzerbeißern konfrontiert". Cytowany fragment dyskursu stawia w opozycji silnych i słabych mężczyzn. Mężczyźni, których potrzebuje kraj, to ci, którzy nie boją się pogłaskać psa obronnego (Kampfhundstreichlern), którzy jadą pod prąd, wyprzedzając (Geisterfahrerüberholern), mówią do policjanta na „ty” (Polizistenduzern), chuligani (Hooligananremplern), rozgryzający kostkę lodu (Eiswürfelzerbeißern). W opozycji do nich stoją mężczyźni określeni pejoratywnie, tzn. oddający mocz na siedząco (omawiany Sitzpinkler), przechodzący przez ulicę na przejściu (Zebrastreifenbenutzer), klaszczący podczas lądowania samolotu (Landungsklatscher), zapinający pasy (Anschnaller), zmywający natychmiast po jedzeniu (Sofortspüler) i czytający podręczniki (Handbuchleser). Lakuna Sitzpinkler jest więc słowem stygmatem, ponieważ grupa mężczyzn przez nią określana jest deprecjonowana, druga zaś prezentowana jest pozytywnie ("Starke Männer braucht das Land”).

Przywołane fragmenty dyskursów przedstawiają niekorzystny obraz niemieckiego mężczyzny określanego absolutną lakuną językową Sitzpinkler. Dosłowne znaczenie tego pojęcia

17 Por.: [online: https://www.buurtaal.de/blog/warmduscher-schattenparker; data dostępu: 18.07.2020]. 
(mężczyzna oddający mocz na siedząco) zyskuje w kontekście znaczenie aktualne, mające negatywne konotacje (mięczak, słabeusz), a więc zyskuje jednocześnie status słowa stygmatu.

\section{der Schattenparker (I.mn. Schattenparker)}

Leksem Schattenparker nie występuje jako hasło w słowniku jednojęzycznym DUDEN. Na jego znaczenie składa się złożenie słów Schatten - 'cień' i Parker - 'parkujący' (kierowca). Dosłownie oznacza kierowcę parkującego w cieniu. Poniżej zostaną zaprezentowane konteksty, w których występuje absolutna lakuna językowa Schattenparker.

1. Na stronie internetowej thelocal.de ${ }^{18} 11$ lipca 2019 roku zamieszczono następujący cytat: „Er macht es nicht, weil er seine Hände nicht schmutzig machen will - Er ist so ein Schattenparker!". Zaimek osobowy (er) wskazuje na fakt, iż mowa jest o mężczyźnie, który nie chce sobie brudzić rąk. Autor wypowiedzi nie jest bliżej określony, ma on jednak negatywny stosunek do osoby, o której mówi. Świadczy o tym wykrzyknienie „so ein Schattenparker!” będące wyzwiskiem, obelgą. Omawiana lakuna absolutna jest $w$ tym fragmencie słowem kluczem, gdyż wskazuje na temat tekstu, a jednocześnie słowem stygmatem, ponieważ określa mężczyznę, który nie jest w stanie podjąć się jakiegoś działania z obawy, że się ubrudzi, co wywołuje negatywne konotacje.

2. Na stronie internetowej urbandictionary.com ${ }^{19}$ użytkownik Delden zamieścił 24 listopada 2009 roku definicję na topie (Top Definition ${ }^{20}$ ) lakuny Schattenparker: „German word for a person who parks under a trees shadow instead of real burning sun. Not a real man, he is afraid that his car becomes hot then. He should let this parking spot empty for pregnant and older people. Maybe »shadowparker« is a equal translation. Look at this guy, he watches girls movies, what a Schattenparker".

Pod pojęciem Schattenparker kryje się określenie mężczyzny parkującego w cieniu drzew zamiast $w$ palącym słońcu. Nie jest on prawdziwym mężczyzną („not a real man”), ponieważ boi się, że zagrzeje mu się samochód. Zajmuje więc miejsce przeznaczone dla kobiet $w$ ciąży i starszych ludzi. Ponadto twórca definicji w słowniku miejskim (urban dictionary) odnosi określenie Schattenparker do mężczyzny, który ogląda filmy dla dziewczyn („he watches girls movies”). W analizowanym fragmencie dyskursu występuje nagromadzenie informacji dotyczących omawianej lakuny absolutnej, co nadaje jej status słowa klucza. Ponadto Schattenparker stygmatyzuje mężczyznę parkującego w cieniu jako kogoś, kto łamie normy społeczne, zgodnie z którymi te miejsca są przeznaczone dla osób objętych przywilejami społecznymi („pregnant and older people”).

3. Na blogu ${ }^{21}$ strony buurtaal.de 22 września 2011 roku zamieszczony został wpis Warmduscher und Schattenparker. W jednym z jego fragmentów pojawia się omawiana lakuna Schattenparker: „Im einundzwanzigsten Jahrhundert haben sich zu diesen notorischen

18 Por: [online: https://www.thelocal.de/20190711/german-word-of-the-day-der-schattenparker; data dostępu: 18.07.2020].

19 Por:: [online: https://www.urbandictionary.com/define.php?term=Schattenparker; data dostępu: 18.07.2020].

${ }^{20}$ Wygrała $w$ rankingu definicji, ponieważ otrzymała najwięcej (26) polubień od innych użytkowników słownika.

${ }^{21}$ Por.: [online: https://www.buurtaal.de/blog/warmduscher-schattenparker; data dostępu: 18.07.2020]. 
Schwächlingen jedoch noch jede Menge anderer Softies gesellt. Die bekanntesten unter ihnen dürften die Warmduscher und die Schattenparker sein. Aber auch Damenradfahrer, Jeansbügler, Helmträger, Frauenversteher, Schwiegermutterrechtgeber, Chefwitzlacher und Socken-in-Sandalen-Träger laufen einem heutzutage regelmäßig über den Weg. Bei kreativen Wortschöpfungen wie diesen wird ein an sich vernünftiges Verhalten (warm duschen, im Schatten parken) durch die Ironiemangel gedreht, sodass es plötzlich nur noch etwas für Hampelmänner zu sein scheint. Andererseits kann man damit auch hervorragend ein tatsächlich unerwünschtes, unbeliebtes oder gesellschaftlich geächtetes Verhalten auf die Schippe nehmen (über schlechte Witze des Chefs lachen, Socken in Sandalen tragen)". Pojęcie Schattenparker zostało zakwalifikowane przez autora tekstu jako jedno z najbardziej znanych określeń notorycznych słabeuszy („,notorischen Schwächlingen”) i mięczaków („Softies”) XXI wieku. Za synonimy do omawianej lakuny zostały uznane słowa: Warmduscher ('biorący prysznic w ciepłej wodzie'), Damenradfahrer ('jeżdżący damskim rowerem, tzw. damką'), Jeansbügler ('prasujący spodnie jeansowe'), Helmträger ('noszący kask ochronny'), Frauenversteher ('rozumiejący kobiety'), Schwiegermutterrechtgeber ('przyznający rację teściowej'), Chefwitzlacher ('śmiejący się z dowcipów szefa') und Socken-in-Sandalen-Träger ('noszący skarpety do sandałów'). Wymienione przez autora synonimy opisują mężczyzn ostrożnych (chroniących stopy czy głowę), poukładanych (prasujących nawet jeansy), niechcących wchodzić w konflikty (z szefem w pracy, z teściową i innymi kobietami w życiu prywatnym). Te kreatywne neologizmy („kreative Wortschöpfungen”), jak określa je sam autor tekstu, opisują mimo wszystko rozsądne zachowanie, ale przez ironię („durch die Ironiemangel gedreht” dosł. "przekręcenie czegoś przez magiel ironii') powstaje ich coraz więcej, tak że niedługo zostanie wymyślony kolejny neologizm określający „pajaców” (PONS, Hampelmänner). Jednocześnie za pomocą tych określeń można szydzić i wyśmiewać niechciany, nielubiany, społecznie potępiany sposób zachowania („gesellschaftlich geächtetes Verhalten”). W analizowanym fragmencie dyskursu lakuna Schattenparker jest słowem kluczem, które zawiera liczne określenia mężczyzny nieodpowiadającego stereotypowemu wizerunkowi. Jednocześnie zyskuje ona status słowa stygmatu, gdyż eksponuje cechy mężczyzn przejawiających rozsądne zachowanie $w$ grupie społecznej, z której za pomocą tzw. kreatywnych neologizmów można się śmiać.

Przeanalizowane fragmenty dyskursów kreują negatywny obraz mężczyzny określanego za pomocą absolutnej lakuny językowej Schattenparker. Znaczenie dosłowne zyskuje negatywne konotacje $w$ kontekście i oznacza słabeusza, mięczaka, pajaca, stygmatyzując osobę określaną mianem Schattenparker.

Obie absolutne lakuny językowe poddane analizie (Sitzpinkler, Schattenparker) mają neutralne znaczenia dosłowne, które jednak w kontekście nabierają negatywnego wydźwięku. Pojawiają się we fragmentach dyskursu jako słowa klucze (DIMEAN), które są głównym tematem tekstu, podkreślają jego przesłanie, a wokół nich są nagromadzone dodatkowe informacje. Znaczenie aktualne analizowanych lakun jest pejoratywne, dlatego też został im nadany status słów stygmatów (DIMEAN). Opisują mężczyzn wyśmiewanych, do których inni żywią silne negatywne emocje. Fragmenty dyskursów wykreowały więc obszar czy wycinek rzeczywistości społecznej, w której mężczyzna należy do grupy albo silnych, albo słabych. Kryterium podziału stanowi zachowanie, które czasem, paradoksalnie, jest 
pozytywne, odbierane jednak przez konkretną grupę jako negatywne. Niemiec siadający na toalecie (co jest pozytywne w oczach kobiet, lecz niewyobrażalne dla Brytyjczyków) czy parkujący $w$ cieniu może zostać obiektem drwin i ironicznych komentarzy, gdyż jego postępowanie odbiega od powszechnie obowiązujących norm i stygmatyzuje go jako słabeusza, mięczaka, pajaca.

\section{Podsumowanie}

Istnienie absolutnych lakun językowych związane jest ze specyfiką zasad niemieckiego słowotwórstwa, dającego znacznie więcej możliwości tworzenia tego typu złożeń niż język polski. Wymienione przykłady rekonstrukcji znaczeń absolutnych lakun językowych mogłyby (odpowiednio sformułowane) uzupełnić polskojęzyczne słowniki o brakujące leksemy (lakuny) i ich definicje leksykalne uwzględniające znaczenia aktualne, wywodzące się z kontekstu. Warto zaznaczyć, iż nie istnieją stałe znaczenia, są one zawsze określane przez kontekst. Ponadto leksykografowie mogliby wykorzystać kontekst dyskursywny do tworzenia haseł słownikowych. Przykłady użyć w słownikach są elementem artykułu hasłowego, nie są one jednak poddawane analizie ani wyjaśniane, a analiza dyskursu umożliwia ich interpretację $w$ kontekście społeczno-kulturowym. Co więcej, znajomość założeń KAD może zostać wykorzystana do właściwej identyfikacji znaczenia w kontekście wybranych lakun niemieckojęzycznych $w$ tłumaczeniu ich na język polski.

\section{Źródła}

https://www.buurtaal.de/blog/warmduscher-schattenparker; data dostępu: 18.07.2020.

https://www.dwds.de/wb/Sitzpinkler; data dostępu: 15.07.2020.

https://www.mundmische.de/bedeutung/4596-Winselstute; data dostępu: 17.07.2020.

https://www.theguardian.com/commentisfree/2010/aug/21/unthinkable-having-a-sit-down; data dostępu: 18.07 .2020 .

https://www.thelocal.de/20190711/german-word-of-the-day-der-schattenparker; data dostępu: 18.07.2020.

https://www.urbandictionary.com/define.php?term=Schattenparker; data dostępu: 18.07.2020.

\section{Słowniki}

DEPL - Słownik online niemiecko-polski, polsko-niemiecki [online: http://www.depl.pl; data dostępu: 10.07.2020].

DIKI - Multimedialny słownik niemieckiego online [online: http://www.diki.pl/slownik-niemieckiego; data dostępu: 10.07.2020].

DUDEN - Deutsches Universalwörterbuch online [online: https://www.duden.de; data dostępu: 10.07.2020].

LANGENSCHEIDT - Słownik internetowy [online: https://pl.langenscheidt.com/niemiecki-polski; data dostępu: 10.07.2020].

PONS - Słownik online [online: https://de.pons.com; data dostępu: 10.07.2020]. 
Agricola E., 1982: Ein Modellwörterbuch lesikalisch-semantischer Strukturen. In: AgricolA E., Schildt J., Viehweger D., Hrsg.: Wortschatzforschung heute. Aktuelle Probleme der Lerikologie und Lerikographie. VEB Verlag Enzyklopädie. Leipzig, s. 7-22.

AuER P., 1999: Sprachliche Interaktion. Eine Einführung anhand von 22 Klassikern. Max Niemeyer Verlag. Tübingen.

BARtMiński J., 2016: Słowa klucze, kulturemy, koncepty kulturowe. „Przegląd Humanistyczny” 2016, R. LX, nr 3 (454), S. 21-28.

Bentivogli, L., Pianta E., 2000: Looking for lerical gaps. In: Heid U., ed.: Proceedings of the Ninth EURALEX International Congress. Universität Stuttgart. Stuttgart, s. 663-669.

BusSE D., 1987: Historische Semantik. Klett-Cotta. Stuttgart.

Busse D., 2000: Historische Diskurssemantik. Ein linguistischer Beitrag zur Analyse gesellschaftlichen Wissens. In: Stukenвrock A., Scharloth J., Hrsg.: Linguistische Diskursgeschichte, s. 39-53.

Busse D., 2007: Diskurslinguistik als Kontentualisierung: Methodische Kriterien. Sprachwissenschaftliche Überlegungen zur Analyse gesellschaftlichen Wissens. In: WARNKE I., Hrsg.: Diskurslinguistik nach Foucault. Theorie und Gegenstände. Walter de Gruyter. Berlin-New York, s. 81-105.

BußMANN H., 1990: Lexikon der Sprachwissenschaft. Alfred Kröner Verlag. Stuttgart.

CzAchur W., 2020: Lingwistyka dyskursu jako integrujący program badawczy. ATUT. Wrocław.

CzerWiński M., 2016: Semiotyczna analiza tekstu. W: CzAchur W., KulczyńskA A., KumięGA Ł., red.: Jak analizować dyskurs? Perspektywy dydaktyczne. Universitas. Kraków, s. 41-58.

ERtelt-Vieth A., 2005: Interkulturelle Kommunikation und kultureller Wandel. Eine empirische Studie zum russisch-deutschen Schüleraustausch. Gunter Narr Verlag: Tübingen.

Ertelt-Vieth A., 2006: Weiterentwicklung des Lakunen-Modells und der Lakunen-Theorie: ariologische Lakunen, Dreiteilung des Modells, Symbole. In: PAnAsıuk I., Schröder H., Hrsg.: LakunenTheorie. Ethnopsycholinguistische Aspekte der Sprach- und Kulturforschung. LIT. Berlin, s. 49-72.

GıÜск H., 1993: Metzler Lerikon Sprache. J.B. Metzler. Stuttgart-Weimar.

Gouws R., Prinsloo D.J., 2008: What to Say about mañana, totems and dragons in a Bilingual Dictionary? The Case of Surrogate Equivalence. In: Bernal E., DeCASARIs J., eds.: Proceedings of the XII EURALEX International Congress. Institut Universitari de Linguistica Aplicada, Universitat Pompeu Fabra. Barcelona, s. 869-877.

Grodzki E., 2003: Using Lacuna Theory to Detect Cultural Differences in American and German Automotive Advertising. Peter Lang. Frankfurt/Main.

Gumperz J.J., 1982: Discourse Strategies. Cambridge University Press. Cambridge.

JÄGER S., 2004: Kritische Diskursanalyse. Eine Einführung. UNRAST-Verlag. Münster.

Kessel K., Reimann S., 2017: Basiswissen Deutsche Gegenwartssprache. 5. überarbeitete und erweiterte Auflage. A. Francke Verlag. Tübingen.

Knipf-Komlósı E., Rada R., Bernáth C., 2006: Aspekte des deutschen Wortschatzes. Ausgewählte Fragen zu Wortschatz und Stil. Bölcsész Konzorcium. Budapest.

Kumį̧GA Ł., Nowıcka M., 2012: Dyskurs o badaniach nad dyskursem w Niemczech. „Oblicza Komunikacji", nr 5, s. 129-154.

Markowskı A., 2012: Wykłady z leksykologii. Wydawnictwo Naukowe PWN. Warszawa.

MARKovina I.J., SOROKIN J.A., 2006: Systematisierungsvergleich linguistischer und kultureller Lakunen. In: PAnAsiuk I., Schröder H., Hrsg: Lakunen-Theorie. Ethnopsycholinguistische Aspekte der Sprach- und Kulturforschung. LIT. Berlin, s. 21-34.

Panasıuk I., 2001: Tabu als Aspekt der Fremdheitswiedergabe in der literarischen Übersetzung: Anwendung des Lakunen-Modells auf die Übersetzungsanalyse von tabuisierten Literaturtexten. In: 
Proкорсzик O., red.: Wschód - Zachód Pogranicze kultur. Kultura - Literaturoznawstwo - Językoznawstwo. (Materiały z II Międzynarodowej Konferencji Naukowej Słupsk 14-15.09.2000 r.). Pomorska Akademia Pedagogiczna. Słupsk, s. 294-303.

PAnAsıuk I., 2005: Kulturelle Aspekte der Übersetzung. Anwendung des ethnopsycholinguistischen Lakunen-Modells auf die Analyse und Übersetzung literarischer Texte. LIT Verlag. Münster-Berlin-Hamburg-London-Wien.

PAnAsıuk I., 2006: Lakunen-Theorie und Äquivalenzproblematik. In: PAnAsıuk I., SCHRÖDER H., Hrsg.: Lakunen-Theorie. Ethnopsycholinguistische Aspekte der Sprach- und Kulturforschung. LIT. Berlin, s. 85-111.

PanAsıuk 1., 2009: Probleme der Übersetzung von Kulturen: Anwendung des Lakunen-Modells auf die Analyse und Übersetzung literarischer Teute. In: Hess-Lütтıch E.W.B., Hrsg.: Translation und Transgression. Interkulturelle Aspekte der Übersetzung. Peter Lang. Frankfurt a/M., s. 243-271.

PANASIUK I., Schröder H., 2006a: Thematische Einleitung: Ethnopsycholonguistik. In: PANASIUK I., SCHRÖDER H., Hrsg.: Lakunen-Theorie. Ethnopsycholinguistische Aspekte der Sprach- und Kulturforschung. LIT. Berlin, s. 13-18.

PANASIUk I., Schröder H., 2006b: Lakunen-Theorie. Ethnopsycholinguistische Aspekte der Sprachund Kulturforschung. LIT. Berlin.

Schippan Th., 1984: Lexikologie der deutschen Gegenwartssprache. Bibliographisches Institut Leipzig. Leipzig.

Seidel-Slotty I., 1960: Die Bedeutung der Wörter, Sprache und Gesellschaft. VEB Verlag Sprache und Literatur. Haale (Saale).

SpIESS C., 2010: Lingwistyczna analiza dyskursu jako analiza wielopoziomowa. Przyczynek do problematyki wielowymiarowego opisu dyskursów z perspektywy praktyczno-naukowej. „Tekst i Dyskurs - Teyt und Dyskurs", nr 3, s. 199-220.

Spitzmüller J., Warnke I., 2011: Diskurslinguistik. Eine Einführung in Theorien und Methoden der transtertuellen Sprachanalyse. Walter de Gruyter. Berlin-Boston.

SYnowIEC A., 2013: W stronę analizy tekstu - wprowadzenie do teorii dyskursu. „Zeszyty Naukowe Politechniki Śląskiej", Seria: Organizacja i Zarządzanie, z. 65, nr. kol. 1897, s. 383-396.

Szerszunowicz J., 2013: Lakunarność jednostki Matka Polka a jej dwujęzyczny opis słownikowy. „Prace Językoznawcze” XV, 2, s. 69-82.

Szerszunowicz J., 2016: Lakunarne jednostki wielowyrazowe w perspektywie międzyjęzykowej. Wydawnictwo Uniwersytetu w Białymstoku. Białystok.

TOPCZEWSKA U., 2005: Konotacje jako problem translatoryczny na przykładzie wyrażeń frazeologicznych. W: Hejwowskı K., red.: Kulturowe i językowe źródła nieprzekładalności. Wszechnica Mazurska. Olecko, s. 245-252.

WARnKe I., 2007: Diskurslinguistik nach Foucault, Theorien und Gegenstände. Walter de Gruyter. Berlin-New York.

Warnke I., Spitzmüller J., 2008: Methoden und Methodologie der Diskurslinguistik - Grundlagen und Verfahren einer Sprachwissenschaft jenseits teutueller Grenzen. In: WARNKE I., SPITZMÜLLER J., Hrsg.: Methoden der Diskurslinguistik. Sprachwissenschaftliche Zugänge zur transtertuellen Ebene. Walter de Gruyter. Berlin-New York, s. 3-54.

WierzbickA A., 1997: Understanding Cultures through Their Key Words. English, Russian, Polish, German, and Japanese. Orford University Press. Ouford 1997. Polski przekład: Słowa klucze. Różne języki - różne kultury. Wydawnictwa Uniwersytetu Warszawskiego. Warszawa 2007. 